\title{
How metal-tolerant ecotypes of ectomycorrhizal fungi protect plants from heavy metal pollution
}

\author{
Jan V. Colpaert • Jan H.L. Wevers • Erik Krznaric • \\ Kristin Adriaensen
}

Received: 16 March 2010 / Accepted: 7 June 2010 / Published online: 28 January 2011

(C) The Author(s) 2011. This article is published with open access at Springerlink.com

\begin{abstract}
- Introduction Heavy metal pollution is a strong driver of above- and belowground communities and triggers evolutionary adaptation in organisms. This review provides an overview of our knowledge on the effects of toxic concentrations of metals on ectomycorrhizal populations and communities.

- Discussion Selection and adaptations within particular ectomycorrhizal species that colonise host plants in harsh environments is discussed. Among these adaptations, we focus on the metal exclusion strategy that is discovered in metal-tolerant ecotypes of Suillus species that thrive on metalliferous soils. Metal efflux in metaltolerant ecotypes prevents metal overloading of cytoplasm and vacuole. At the same time, this metal-specific efflux system in Suillus seems to reduce the transfer of large quantities of metals towards the plant-fungus interface, without hampering normal nutrient transfer to the host plant.

- Conclusion The evolutionary adaptation in Suillus species contributes to the survival of host trees on metalliferous soils and might be exploited in phytostabilisation strategies for heavy metal-contaminated soils.
\end{abstract}

Keywords Heavy metal pollution · Heavy metal tolerance Ectomycorrhizal fungi $\cdot$ Pinus sylvestris $\cdot$ Suillus luteus

Handling Editor: Jean Garbaye

J. V. Colpaert $(\bowtie) \cdot J$. H. Wevers $\cdot$ E. Krznaric $\cdot$ K. Adriaensen Environmental Biology Group,

Centre for Environmental Sciences, Hasselt University,

Agoralaan, Gebouw D,

3590 Diepenbeek, Belgium

e-mail: jan.colpaert@uhasselt.be

\section{Ectomycorrhizal fungi on metalliferous soils}

Soils that contain high concentrations of heavy metals, whether from natural origin or from anthropogenic activity, may pose considerable challenge to exposed biota. Although some of these metals like $\mathrm{Cu}, \mathrm{Fe}, \mathrm{Mn}$, and $\mathrm{Zn}$ are essential micronutrients required for a wide variety of cellular processes, they eventually become toxic to most biota including plants and their associated mycorrhizal fungi. Nevertheless, it has been suggested several times that micro-organisms in general exhibit higher tolerance against metal toxicity than plants (Hartley et al. 1997). Such a general pattern is difficult to prove, especially since our knowledge on above- and belowground communities and processes is rather different, the soil being a black box in both literal and figurative sense. Knowledge on composition and dynamics of microbial soil communities is still emerging and rather fragmentary, in contrast to our knowledge of plant communities and succession on metalliferous soils. Naturally metal-enriched sites are often characterised by unique vegetation that includes several metal-adapted species or ecotypes, some of which are endemic and (or) metal hyperaccumulators. Some of these rarities are elaborately investigated to examine the molecular mechanisms that evolved in these plants to cope with excess heavy metals (Verbruggen et al. 2009).

Some recent studies on communities of ectomycorrhizal (ECM) fungi on serpentine soils are not consistent with the important endemism in the aboveground plant communities (Moser et al. 2009). Serpentine soils, rich in iron, magnesium, and heavy metals, select for unique plant communities and for endemic species. However, mycorrhizal communities on serpentine and nonserpentine soils were not significantly different; ECM fungi associated with Quercus garryana were neither reduced nor excluded by serpentinite or peridotite parent materials. A broad taxonomic range of ECM fungi 
seems to have the potential to successfully colonise tree roots under the extreme edaphic conditions of serpentine soils (Moser et al. 2009; Urban et al. 2008) and also on anthropogenically contaminated sites investigators do not find specific metal-adapted taxa (Blaudez et al. 2000a; Krpata et al. 2008). Highly adapted ECM fungi with a distribution restricted to metalliferous soils have not been reported. Some authors suggested that there is little evolutionary adaptation towards elevated tolerance in ECM fungal communities as there might be sufficient ECM fungi with a high constitutive tolerance that are selected for and thus become dominant in metal-contaminated environments (Blaudez et al. 2000a; Meharg and Cairney 2000). Nevertheless, significant shifts in ECM communities in extreme environments have been observed (Colpaert 2008; Ruotsalainen et al. 2009; Staudenrausch et al. 2005) and sometimes ECM fungi are wiped out in favour of dark septate endophytes (DSEs) (Likar and Regvar 2009). The latter authors observed a dominance of ascomycetes in the most polluted plots along a $\mathrm{Pb}$ gradient, while there was a greater diversity of basidiomycetes in the less polluted and control plots, suggesting greater stress tolerance of ascomycetes in comparison to basidiomycete fungi. The dominance and high diversity of DSEs was characteristic for the highly metal-enriched locations, with species belonging to the genera Phialophora, Phialocephala and Leptodontidium. Furthermore, the DSE colonisation of Salix caprea roots and the frequency of Phialophora-like species (DSE genus) correlated positively with soil $\mathrm{Pb}, \mathrm{Cd}$ and plant-available $\mathrm{P}$ concentrations. Also the DSE ascomycete, Cadophora finlandica, has been regularly reported as a mycobiont on metal-contaminated sites (Gorfer et al. 2009; Utmazian et al. 2007). Dark ascomycetes belonging to the Hymenoscyphus ericae aggregate were recorded on pine roots from a $\mathrm{Cu}$ mine spoil in Folldal, Norway (Vrålstad et al. 2002) and from the $\mathrm{Zn} / \mathrm{Cd}$ polluted site in Lommel-Maatheide, Belgium.

Apart from dark ascomycetes, the metalliferous sites in Norway and Belgium also harbour an important population of the basidiomycete ECM fungus: Suillus luteus, an obligate mycobiont of pine trees and a typical pioneer fungus that is very common in primary successions on polluted and nonpolluted sites. Other basidiomycete taxa that have been frequently found - but certainly not exclusively — on heavy metal-polluted soils include Hebeloma sp., Pisolithus sp. (Jourand et al. 2010; Turnau et al. 1988), Rhizopogon sp. (Turnau et al. 1996), Scleroderma sp. (Jones and Hutchinson 1986) and Amanita muscaria (Gast et al. 1988).

\section{Metal toxicity triggers evolutionary processes towards higher metal tolerance}

In those environments where heavy metal availability does rise to levels that reduce ECM diversity or clearly alters species composition of ECM fungal communities, one might expect selection pressure on the fungal populations. For plants, such an influence of soil metal toxicity can easily be demonstrated and there is a lot of evidence for the evolution of adaptive metal tolerance in higher plants, e.g., in grass species (Al-Hiyaly et al. 1990; Bradshaw and McNeilly 1981). Such evidence is only recently coming up for ECM fungi. Adaptive metal tolerance has been suggested for a few higher fungi, including Pisolithus tinctorius and Pisolithus albus (Egerton-Warburton and Griffin 1995; Jourand et al. 2010), Suillus species (Colpaert et al. 2000; 2004; Krznaric et al. 2009), Cenococcum geophilum (Goncalves et al. 2009) and some other ascomycetes. Ecotypes are specifically adapted against $\mathrm{Al}$, $\mathrm{Ni}, \mathrm{Zn}, \mathrm{Cd}$ or $\mathrm{Cu}$. Similar to the situation in the plant world, evolution for metal-tolerant ecotypes shows up in a small number but ever recurring species. It is remarkable that some organisms seem to be predestined to evolve specific metal-tolerance mechanisms. Such particular species are well-known among prokaryotes (Mergeay et al. 2003; von Rozycki and Nies 2009) and plants (Ernst 1990; Schat et al. 2000). These organisms can acquire tolerances against many different metals. In bacteria, plasmids play a major role in this multiple heavy metal tolerance. In most eukaryotic organisms, true adaptation seems to be governed by a relatively small number of genetic determinants (Verbruggen et al. 2009; Willems et al. 2010). Nevertheless, such genetic modifications occur slowly, in particular in species with long reproductive cycles.

Although trees are rarely considered as primary colonisers of metal-polluted soils (Schat et al. 2000), a number of tree species, including willows, poplars, birches and pines are able to build up pioneer populations under harsh environmental conditions. In Europe, different Pinus species, the typical host plants of Suilloid fungi are found on mining and smelter sites from the boreal to the mediterranean climate and from atlantic to continental Europe (Adriaensen et al. 2005; Colpaert et al. 2004; Johansson et al. 2005; Vrålstad et al. 2002). In these primary successions with pine trees, Suillus and Rhizopogon species are typical members of the fungal ECM communities. In trees with their long reproductive cycles, the adaptive potential for metal tolerance is probably low (Meharg and Cairney 2000), and even if there is selection for individuals with a higher tolerance, it may take many decades before a reasonable tolerant population is build up. Apart from the lack of fast evolution for metal tolerance in woody plants, there is another reason why colonisation of metal-contaminated soils by trees may be very slow. Woody pioneers rely much more on their ECM fungi than herbaceous pioneer plants that might be nonmycorrhizal or have a low dependency on arbuscular mycorrhizal fungi. ECM fungi in contrast are essential for the establishment of woody species during primary succes- 
sion (Ashkannejhad and Horton 2006; Nara 2006a, b). Nevertheless, despite the hostile environment, the ECM symbiosis persists on strongly metal-contaminated sites that are slowly colonised by highly mycotrophic Pinus species. Therefore, one can only conclude that pines resist extreme metal toxicity through a large phenotypic plasticity and through their association with a small guild of well-adapted ECM fungi (Wilkinson and Dickinson 1995), including dark ascomycetes and some metal-tolerant basidiomycetes.

\section{Metal homeostasis in ectomycorrhizal fungi}

The mechanisms that are involved in metal homeostasis and detoxification of essential and non-essential metals in ECM fungi are probably not different from those that are present in other eukaryotes (Bellion et al. 2006; Courbot et al. 2004). Extracellular mechanisms such as precipitation, chelation and cell-wall binding as well as intracellular mechanisms such as binding to organic acids, sulfur compounds, polyphosphates, peptides and transport into intracellular compartments play a role in the metal housekeeping of ECM fungi. Some of these mechanisms are constitutively present, whereas others are induced when excess metals show up in the cytoplasm. Additional antioxidative detoxification systems, which allow the fungus to counteract the accumulation of reactive-oxygen species directly or indirectly, are part of the detoxification response (Bellion et al. 2006). It is likely that one or more of these mechanisms are modified in the evolution towards true adaptive tolerance in ECM fungi.

\section{A case study: the adaptive metal tolerance in Suillus species}

Suillus species are an important group of root symbionts of pioneer pine trees that colonise severely polluted sites. Examples of adaptive metal tolerance have been described in this genus, and mechanisms possibly involved in the adaptive tolerance are investigated. Among the European Suilloid representatives, $S$. luteus is a species with a very distinct pioneer behaviour. Its basidiospores are most likely dispersed by wind and mammals (Ashkannejhad and Horton 2006). Its frequent and early sexual reproduction with the release of billions of basidiospores are a trade mark of its pioneer behaviour and may favour rapid selection for genotypes adapted to specific soil conditions. It has evolved ecotypes that are specifically tolerant against high $\mathrm{Zn}, \mathrm{Cd}$ or $\mathrm{Cu}$ concentrations (Adriaensen et al. 2005; Colpaert et al. 2000). For Suillus bovinus, a species that quickly follows in the succession, adaptive tolerance against $\mathrm{Zn}$ was also recorded (Colpaert et al. 2004). Elevated metal tolerance is probably just a specific case of the general demand of every living cell for some metal homeostatic system. Metals, whether they are essential micronutrients or not, become toxic when their free ion concentration passes some threshold level in the cytoplasm. For the transition metals, $\mathrm{Cu}$ and $\mathrm{Zn}$, the free concentration is estimated to be less than one free ion per cell (Krämer et al. 2007). To achieve this, the intracellular concentration of metal ions has to be tightly controlled, and organisms have a whole battery of molecules and regulatory mechanisms at their disposal to mobilise sufficient micronutrients, to build up a small storage pool and to avoid damage by excess metals. Therefore, metal uptake must be regulated and well coordinated with detoxification and storage mechanisms. Homeostasis of essential transition metals such as $\mathrm{Cu}$ and $\mathrm{Zn}$ requires balanced activities of transporters that mediate import into the cell, distribution to organelles and export from the cell (Pilon et al. 2009). Transcriptional control is important for the regulation of this cellular homeostasis. Nevertheless, when metals are present in very high concentrations in the environment, the regulatory mechanisms may fail and selection pressure for a more robust homeostasis will increase. Several specific adaptations have been described in a number of eukaryotic organisms, but only some of these were explored in ECM fungi (Bellion et al. 2006).

Since mycorrhizal fungi are usually involved in phosphorus and trace element mobilisation under nutrient limiting conditions, they often exude significant quantities of organic acids and protons (Arvieu et al. 2003; Fomina et al. 2005; Johansson et al. 2008). In metalliferous soils, an adjustment of this process may provide some selective advantage. A shift towards more oxalate release with concomitant precipitation of metals or a lower extracellular acidification can reduce the bioavailable fraction and thus toxicity of metals. Such an adaptation was discovered in strains of the ericoid mycorrhizal fungus Oidiodendron maius isolated from polluted soils. These $\mathrm{Zn}$-tolerant ecotypes showed little ability to solubilise $\mathrm{Zn}$ from both $\mathrm{ZnO}$ and $\mathrm{Zn}_{3}\left(\mathrm{PO}_{4}\right)_{2}$, whereas strains from unpolluted soils showed a higher solubilisation potential (Martino et al. 2003). S. luteus and S. bovinus also cause an extracellular acidification, but a differential exudation pattern was not found.

Another extracellular barrier against excess metals in the environment is the cell wall. The physiological advantage of metal sorption on the cell wall is strong metabolic inactivation with a low cost. Fungal mycelia often have a high sorption capacity for metals, so binding of metals in the apoplast may represent a substantial fraction of the metal accumulated by mycelia (Gadd 1993). Also, ECM fungi can bind substantial amounts of metals (Blaudez et al. 2000 b), although it is unlikely that this binding is an 
efficient strategy to avoid metals from entering into cells. Within minutes, binding sites in hyphal walls are saturated with metals when submerged in solutions containing high metal concentrations. Once the equilibrium with the surrounding soil solution is reached, the protective role of the cell wall is probably small because it cannot change metal availability at the plasma membrane. Hyphae of many ECM fungi are covered with a monolayer of small water-repellent proteins, hydrophobins, which probably can affect the uptake of metals from soil solution. The hydrophobic barrier has a primary role in maintaining hydraulic balances within mycelia but can act as a nonspecific filter for metals. In a $\mathrm{Zn}$ compartmentation study with $S$. bovines, significant amounts of $\mathrm{Zn}$ were sequestered in the apoplast, but the specific $\mathrm{Zn}$ sorption per unit biomass was similar for $\mathrm{Zn}$-tolerant and sensitive ecotypes (Fig. 1). Therefore, sequestration of $\mathrm{Zn}$ in the $S$. bovinus cell wall cannot explain the differential $\mathrm{Zn}$ tolerance of the isolates. A similar pattern was observed for Cd-tolerant and sensitive S. luteus.

Despite extracellular chelation and cell-wall binding, large amounts of metal eventually enter into Suillus hyphae that are exposed to excess metals. However, exposing $\mathrm{Zn}$ and Cd-tolerant ecotypes to elevated $\mathrm{Zn}$ or $\mathrm{Cd}$ concentrations in vitro results in a strong differential net uptake of $\mathrm{Zn}$ and $\mathrm{Cd}$ when compared to strains from non-polluted sites (Fig. 2) (Colpaert et al. 2005). For both metals, tolerant ecotypes accumulate less metal per unit biomass, indicating a metal exclusion system. When mycelial pellets cultivated in liquid cultures are transferred to a sublethal dose of $\mathrm{Cd}(45 \mu \mathrm{M})$, sensitive and tolerant isolates accumulate similar amounts of $\mathrm{Cd}$ within the first $2 \mathrm{~h}$, but soon after this period, they start to differentiate in $\mathrm{Cd}$ content. In sensitive isolates, $\mathrm{Cd}$ content further increases (up to $48 \mathrm{~h}$ ), whereas in Cd-tolerant isolates, a decrease in Cd content becomes apparent (Fig. 3). After 48 h, sensitive ecotypes have accumulated twice as much $\mathrm{Cd}$ than tolerant isolates. Since net accumulation of metals in mycelia is the
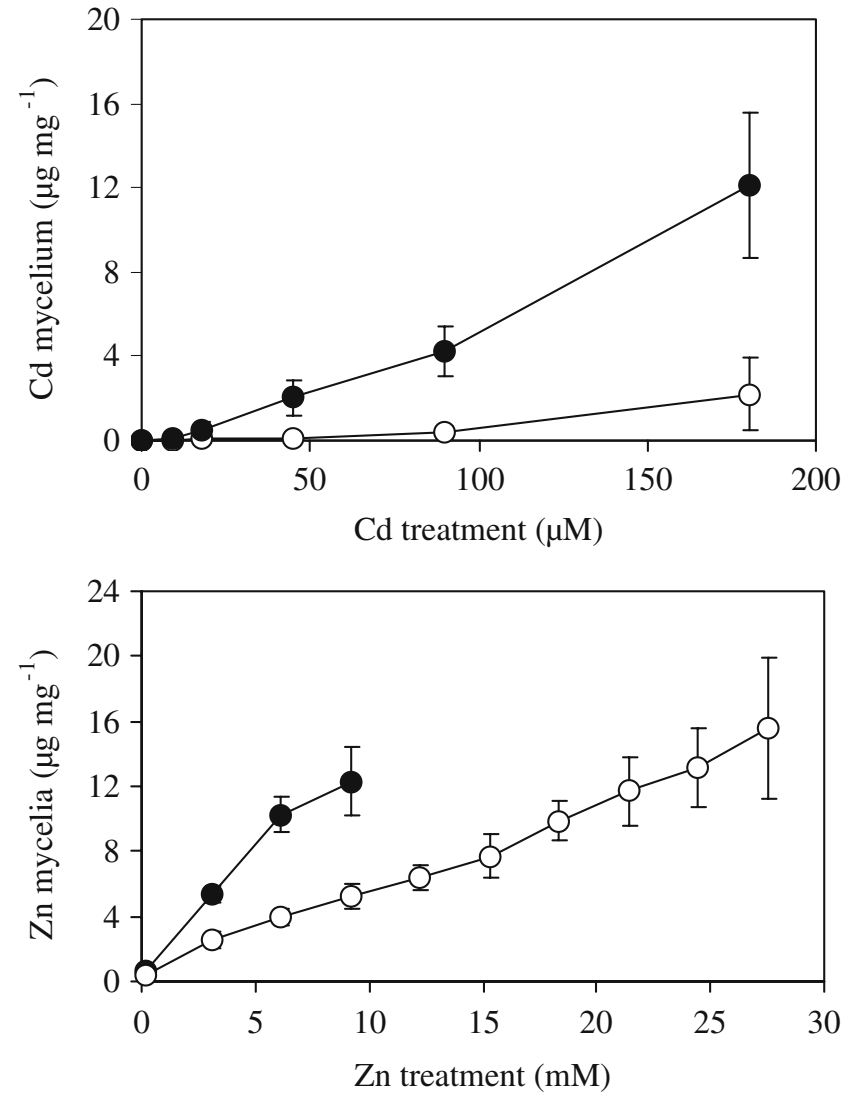

Fig. $2 \mathrm{Cd}$ and $\mathrm{Zn}$ accumulation in Suillus luteus mycelia grown for 10 days on a $\mathrm{Cd}$ and $\mathrm{Zn}$ gradient in agar medium. Averages of a metalsensitive population (black circle) and a metal-tolerant population (white circle), $n=5$ isolates, bars represent $\mathrm{SD}$

result of the balance between influx and efflux, tracer studies were performed to investigate the unidirectional fluxes of $\mathrm{Zn}$ and $\mathrm{Cd}$. These experiments confirm that intracellular fractions of $\mathrm{Zn}$ and $\mathrm{Cd}$ are far lower in the tolerant ecotypes compared to the sensitive individuals (Fig. 1). The influx study with ${ }^{65} \mathrm{Zn}$ and ${ }^{109} \mathrm{Cd}$ did not reveal a substantial difference in $\mathrm{Zn}$ or $\mathrm{Cd}$ influx. However,
Fig. $1 \mathrm{Zn}$ and Cd compartmentation in tolerant and sensitive ecotypes of Suillus bovinus (Zn) and S. luteus (Cd). Mycelial pellets from liquid cultures were loaded with radiolabel for $24 \mathrm{~h}$. Radiotracer efflux analysis was performed to calculate metal content of each compartment
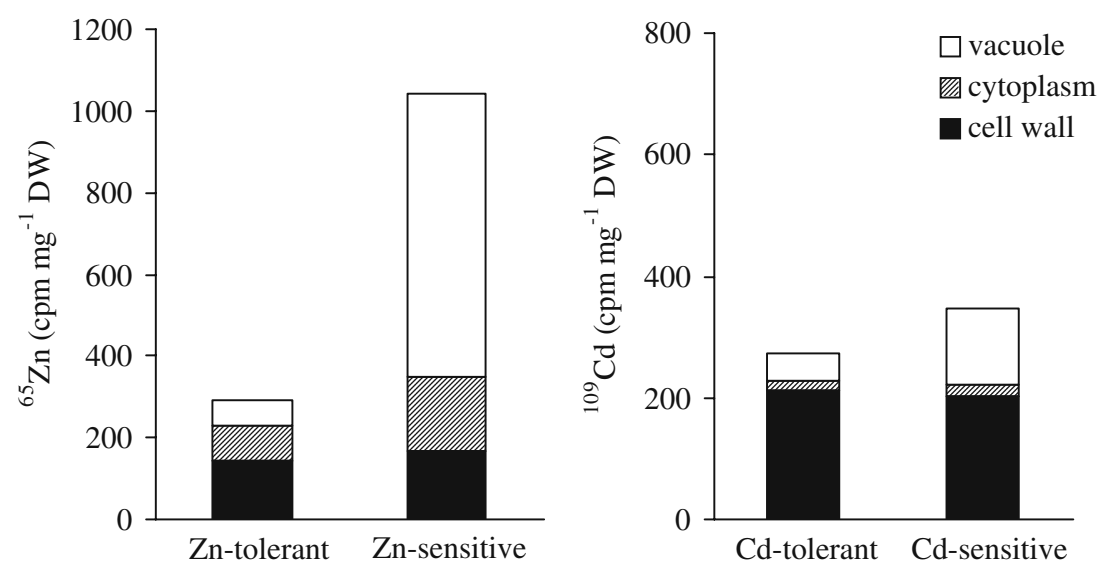


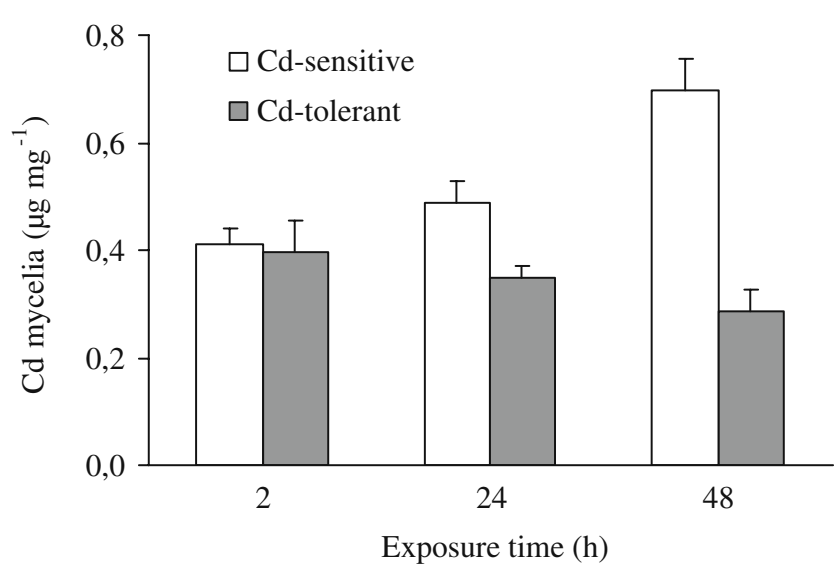

Fig. 3 Time course of the accumulation of $\mathrm{Cd}$ in $1 \mathrm{~g} \mathrm{FW}$ of Cdtolerant and Cd-sensitive Suillus luteus ecotypes exposed to $45 \mu \mathrm{M}$ $\mathrm{Cd}$ in liquid medium. Bars represent SD $(n=6)$

efflux from the cytoplasmic as well as the vacuolar compartment was significantly faster in tolerant compared to sensitive isolates, resulting in shorter exchange times for both metals in tolerant isolates. In fungi, excess $\mathrm{Zn}$ and $\mathrm{Cd}$ are preferentially transferred to vacuoles (Blaudez et al. 2000b; Simm et al. 2007), where metal ions are probably complexed in a chemically inactive form. Such an efficient transfer of metals into the vacuoles leads to a massive accumulation of these metals in the vacuole, up to $100 \mathrm{mM}$ in Saccharomyces cerevisiae (Simm et al. 2007). However, when too much $\mathrm{Zn}$ continues to enter the cells, the process eventually results in some overloading, a shortage of ligands, an increasing backflow from the vacuole back to the cytoplasm, damage to the tonoplast or a combination of these problems. Any release of metals from the vacuole will lead to increasing metal concentrations and thus damage in the cytoplasm. In the metal-tolerant Suillus ecotypes, an efficient metal export system from the cytoplasm into the apoplast creates a lower net influx and can avoid an overloading of the vacuole at high external metal concen- trations. A similar differential $\mathrm{Zn}$ efflux pattern was previously found for root cells of $\mathrm{Zn}$-sensitive Thlaspi arvense and $\mathrm{Zn}$-tolerant Thlaspi caerulescens (Lasat et al. 1998). T. caerulescens accumulated less $\mathrm{Zn}$ in root cell vacuoles which had a nearly $50 \%$ shorter half-time for $\mathrm{Zn}$ release compared with $T$. arvense. An increased efflux of As was shown to be responsible for the arsenate resistance in mine (As ore) populations from the ericoid mycorrhizal fungus $H$. ericae (Sharples et al. 2000). In recent years, metal selective export systems have been described in some plants and fungi (Adle et al. 2007; Krämer et al. 2007; Peiter et al. 2007; Verbruggen et al. 2009), among these, the heavy metal transporting $\mathrm{P}_{1 \mathrm{~B}}$-ATPases (HMAs) which translocate transition metals out of the cytoplasm across biological membranes, including the plasma membrane, using energy from the hydrolysis of ATP.

\section{The adaptive metal tolerance in Suillus sp. protects pines against toxicity}

Since several decades, researchers have demonstrated that ectomycorrhizal fungi can alleviate metal toxicity in plants (Jentschke and Godbold 2000). In most of these experiments, mycorrhizal plants performed better with a suitable ECM fungus than without; and some fungi were more efficient in improving plant fitness than others (Colpaert and Van Assche 1992). For protection of a host plant that has the potential to grow on a metalliferous soil, three major traits are particularly important for a successful mycorrhizal association: (1) survival of the fungus in the toxic substrate, (2) efficient nutrient transfer to the host, (3) low transfer of the toxic metal to the host plant (Colpaert 2008).

The survival of the ECM fungus is essential to establish the symbiosis. A large interspecific variation in metal sensitivity is observed in in vitro culture studies, although
Table 1 Ratio of metal concentration in needles of Pinus sylvestris inoculated with a metaltolerant ecotype of Suillus luteus or $S$. bovinus versus metal concentration in needles of pines associated with a metal-sensitive ecotype of the same fungus

Tolerant ecotypes were all isolated from metalliferous soil

Each line represents a single metal-ecotype treatment. Data compiled from experiments by Adriaensen et al. 2004; 2005; 2006 and Krznaric et al. 2009; 2010

\begin{tabular}{llll}
\hline Fungus & Metal treatment $(\mu \mathrm{M})$ & Exposure time & {$[$ Metal] needles tolerant vs. control } \\
\hline Suillus luteus & $\mathrm{Cd} 5$ & 8 weeks & 0.53 \\
& $\mathrm{Cd} 10$ & 8 weeks & 0.33 \\
& $\mathrm{Cd} 10$ & 8 weeks & $0.10-0.62$ \\
& $\mathrm{Cd} 10$ & 8 weeks & $0.18-0.69$ \\
& $\mathrm{Zn} 150$ & 8 weeks & $0.69-0.93$ \\
& Zn 150 & 8 weeks & $0.62-0.81$ \\
& $\mathrm{Cu} 30$ & 10 weeks & 0.78 \\
& $\mathrm{Cu} 60$ & 10 weeks & 0.75 \\
Suillus bovinus & Zn 75 & 6 weeks & 0.57 \\
& Zn 150 & 6 weeks & 1.17 \\
& Zn 150 & 9 months & 0.78 \\
\hline
\end{tabular}


it is not sure whether such observations can be extrapolated to the field situation (Blaudez et al. 2000a; Hartley et al. 1997). At least some fungi seem not to withstand metal concentrations in soil solutions of polluted soils. In mycorrhizal plant systems, the external mycelia of wild type metal-sensitive Suillus species suffer severely from Zn, $\mathrm{Cu}$ and $\mathrm{Cd}$ concentrations that do not affect growth of tolerant ecotypes (Adriaensen et al. 2004; 2005; 2006; Krznaric et al. 2009).

Improved plant nutrition is a major function of the ECM symbiosis, and this is not different on metalliferous soils. Most of these soils are very poor in essential nutrients, and pioneer ECM fungi are most suited to exploit such environments. Their external mycelia contribute largely to the nutrient uptake and transfer to the host. Eventually, this improved nutrition leads to a better health and growth of trees inoculated with suited ECM fungi. In comparisons between mycorrhizal and nonmycorrhizal plants, this was demonstrated in several experiments (Jentschke and Godbold 2000). Also, the metal-sensitive and metal-tolerant ecotypes of Suillus spp. have high, similar nutrient uptake capacities (Adriaensen et al. 2004; 2005; Krznaric et al. 2010).

Metal exclusion mechanisms in metal-tolerant ECM fungi not only help to prevent metal stress in the fungal cells, but it is likely to be of ecological importance for a host plant on metalliferous soil. Tolerant ecotypes may act as a better filter than non-tolerant ecotypes because the former more strongly prevent metal transfer to their host. The external mycelial system of many ECM fungi, including Suillus species, can be classified into the longdistance exploration type allowing these fungi to take up nutrients (and metals) from a large soil volume (Agerer 2001). Ashford and Allaway (2002) suggest that motile tubular vacuoles are an important vector in the transport chain of mineral nutrients from the site of uptake at hyphal tips to the exchange region in the mycorrhizal root. The observation that metal-tolerant Suillus ecotypes do not store huge amounts of metals into their vacuoles (Fig. 1) may thus prevent a massive transport of metals towards the mycorrhizas. Pine seedlings inoculated with metal-tolerant Suillus ecotypes in most cases have lower metal concentrations in their needles than seedlings inoculated with sensitive strains (Table 1), indicating that the metal-tolerant isolates restrict metal transfer more effectively and leading to a more efficient partnership with host plants thriving on metal-polluted soil. Such a filter function was also proposed by Turnau et al. (2001) who used micro-PIXE (protoninduced X-ray emission) true elemental maps to identify tissue patterns of metals in cryo-fixed $S$. luteus mycorrhizas collected from $\mathrm{Zn}$ wastes. Zinc ions were concentrated in tissues that make direct contact with the contaminated substrate such as rhizomorphs and the outer fungal mantle.

\section{Conclusion}

High metal concentrations in soil can lead to the evolution of adaptive metal tolerance in some ECM fungi. The adaptation might be a prerequisite for the survival of both trees and fungi on the most toxic soils. Nevertheless, there remains some controversy about the impact of heavy metal pollution on ECM communities and population dynamics, a discussion that can only be solved by additional field studies. We also still have a long way to go towards the discovery of the molecular mechanisms behind the metal adaptations in ECM fungi. In Suillus species, metal exclusion is of major importance for higher tolerance, but other strategies may exist in other fungi. The Suillus case supports the idea that metal exclusion in the ECM fungus can reduce the transfer of metals towards a host plant, a trait that might be exploited in phytostabilisation strategies for metal-contaminated soils. Up to now, our understanding of the metal transport mechanisms in Suillus and filamentous fungi in general is however limited as well as our knowledge on metal detoxification and storage mechanisms. More research in this field is therefore wishful.

Acknowledgements We thank the Fund for Scientific ResearchFlanders for sponsoring the Suillus research (FWO-projects G.0325.05, G.0046.06 and G.0669.06).

Open Access This article is distributed under the terms of the Creative Commons Attribution Noncommercial License which permits any noncommercial use, distribution, and reproduction in any medium, provided the original author(s) and source are credited.

\section{References}

Adle DJ, Sinani D, Kim H, Lee J (2007) A cadmium-transporting $\mathrm{P}_{1 \mathrm{~B}^{-}}$ type ATPase in yeast Saccharomyces cerevisiae. J Biol Chem 282:947-955

Adriaensen K, van der Lelie D, Van Laere A, Vangronsveld J, Colpaert JV (2004) A zinc-adapted fungus protects pines from zinc stress. New Phytol 161:549-555

Adriaensen K, Vrålstad T, Noben JP, Vangronsveld J, Colpaert JV (2005) Copper-adapted Suillus luteus, a symbiotic solution for pines colonizing $\mathrm{Cu}$ mine spoils. Appl Environ Microbiol 71:7279-7284

Adriaensen K, Vangronsveld J, Colpaert JV (2006) Zinc tolerant Suillus bovinus improves growth of $\mathrm{Zn}$-exposed Pinus sylvestris seedlings. Mycorrhiza 16:553-558

Agerer R (2001) Exploration types of ectomycorrhizae - a proposal to classify ectomycorrhizal mycelial systems according to their patterns of differentiation and putative ecological importance. Mycorrhiza 11:107-114

Al-Hiyaly SAK, McNeilly T, Bradshaw AD (1990) The effect of zinc contamination from electricity pylons - contrasting patterns of evolution in 5 grass species. New Phytol 114:183-190

Arvieu JC, Leprince F, Plassard C (2003) Release of oxalate and protons by ectomycorrhizal fungi in response to P-deficiency and calcium carbonate in nutrient solution. Ann For Sci 60:815-821 
Ashford AE, Allaway WG (2002) The role of the motile tubular vacuole system in mycorrhizal fungi. Plant Soil 244:177-187

Ashkannejhad S, Horton TR (2006) Ectomycorrhizal ecology under primary succession on coastal sand dunes: interactions involving Pinus contorta, suilloid fungi and deer. New Phytol 169:345-354

Bellion M, Courbot M, Jacob C, Blaudez D, Chalot M (2006) Extracellular and cellular mechanisms sustaining metal tolerance in ectomycorrhizal fungi. FEMS Microbiol Lett 254:173-181

Blaudez D, Jacob C, Turnau K, Colpaert JV, Ahonen-Jonnarth U, Finlay R, Botton B, Chalot M (2000a) Differential responses of ectomycorrhizal fungi to heavy metals in vitro. Mycol Res 104:1366-1371

Blaudez D, Botton B, Chalot M (2000b) Cadmium uptake and subcellular compartmentation in the ectomycorrhizal fungus Paxillus involutus. Microbiology-UK 146:1109-1117

Bradshaw AD, McNeilly T (1981) Evolution and pollution. Inst Biol Stud Biol 130:1-76

Colpaert JV (2008) Heavy metal pollution and genetic adaptations in ectomycorrhizal fungi. In: Avery SV, Stratford M, Van West P (eds) Stress in yeasts and filamentous fungi. Academic, Amsterdam, pp 157-174

Colpaert JV, Van Assche JA (1992) Zinc toxicity in ectomycorrhizal Pinus sylvestris. Plant Soil 143:201-211

Colpaert JV, Vandenkoornhuyse P, Adriaensen K, Vangronsveld J (2000) Genetic variation and heavy metal tolerance in the ectomycorrhizal basidiomycete Suillus luteus. New Phytol 147:367-379

Colpaert JV, Muller LAH, Lambaerts M, Adriaensen K, Vangronsveld $\mathrm{J}$ (2004) Evolutionary adaptation to zinc toxicity in populations of Suilloid fungi. New Phytol 162:549-559

Colpaert JV, Adriaensen K, Muller LAH, Lambaerts M, Faes C, Carleer $\mathrm{R}$, Vangronsveld J (2005) Element profiles and growth in $\mathrm{Zn}$ sensitive and Zn-resistant Suilloid fungi. Mycorrhiza 15:628-634

Courbot M, Diez L, Ruotolo R, Chalot M, Leroy P (2004) Cadmiumresponsive thiols in the ectomycorrhizal fungus Paxillus involutus. Appl Environ Microbiol 70:7413-7417

Egerton-Warburton L, Griffin B (1995) Differential responses of Pisolithus tinctorius isolates to aluminium in vitro. Can $\mathrm{J}$ Bot 73:1229-1233

Ernst WHO (1990) Mine vegetations in Europe. In: Shaw AJ (ed) Heavy metal tolerance in plants: evolutionary aspects. CRC, Boca Raton, pp 21-37

Fomina MA, Alexander IJ, Colpaert JV, Gadd GM (2005) Solubilization of toxic metal minerals and metal tolerance of mycorrhizal fungi. Soil Biol Biochem 37:851-866

Gadd GM (1993) Interactions of fungi with toxic metals. New Phytol 124:25-60

Gast CH, Jansen E, Bierling J, Haanstra L (1988) Heavy metals in mushrooms and their relationship with soil characteristics. Chemosphere 17:789-799

Goncalves SC, Martins-Loucao MA, Freitas H (2009) Evidence of adaptive tolerance to nickel in isolates of Cenococcum geophilum from serpentine soils. Mycorrhiza 19:221-230

Gorfer M, Persak H, Berger H, Brynda S, Bandian D, Strauss J (2009) Identification of heavy metal regulated genes from the root associated ascomycete Cadophora finlandica using a genomic microarray. Mycol Res 113:1377-1388

Hartley J, Cairney JWG, Meharg AA (1997) Do ectomycorrhizal fungi exhibit adaptive tolerance to potentially toxic metals in the environment? Plant Soil 189:303-319

Jentschke G, Godbold DL (2000) Metal toxicity and ectomycorrhizas. Physiol Plant 109:107-116

Johansson EM, Fransson PMA, Finlay RD, van Hees PAW (2008) Quantitative analysis of exudates from soil-living basidiomycetes in pure culture as a response to lead, cadmium and arsenic stress. Soil Biol Biochem 40:2225-2236
Johansson L, Xydas C, Messios N, Stoltz E, Greger M (2005) Growth and $\mathrm{Cu}$ accumulation by plants grown on $\mathrm{Cu}$ containing mine tailings in Cyprus. Appl Geochem 20:101-107

Jones MD, Hutchinson TC (1986) The effect of mycorrhizal infection on the response of Betula papyrifera to nickel and copper. New Phytol 102:429-442

Jourand P, Ducousso M, Loulergue-Majorel C, Hannibal L, Santoni S, Prin Y, Lebrun M (2010) Ultramafic soils from New Caledonia structure Pisolithus albus in ecotype. FEMS Microbiol Ecol 72:238-249

Krämer U, Talke IN, Hanikenne M (2007) Transition metal transport. FEBS Lett 581:2263-2272

Krpata D, Peintner U, Langer I, Fitz WJ, Schweiger P (2008) Ectomycorrhizal communities associated with Populus tremula growing on a heavy metal contaminated site. Mycol Res 112:1069-1079

Krznaric E, Verbruggen N, Wevers JHL, Carleer R, Vangronsveld J, Colpaert JV (2009) Cd-tolerant Suillus luteus: a fungal insurance for pines exposed to Cd. Environ Pollut 157:1581-1588

Krznaric E, Wevers JHL, Cloquet C, Vangronsveld J, Vanhaecke F, Colpaert JV (2010) Zn pollution counteracts Cd toxicity in metaltolerant ectomycorrhizal fungi and their host plant, Pinus sylvestris. Environ Microbiol 12:2133-2141

Lasat MM, Baker AJM, Kochian LV (1998) Altered Zn compartmentation in the root symplasm and stimulated $\mathrm{Zn}$ absorption into the leaf as mechanisms involved in Zn hyperaccumulation in Thlaspi caerulescens. Plant Physiol 118:875-883

Likar M, Regvar M (2009) Application of temporal temperature gradient gel electrophoresis for characterisation of fungal endophyte communities of Salix caprea L. in a heavy metal polluted soil. Sci Total Environ 407:6179-6187

Martino E, Perotto S, Parsons R, Gadd GM (2003) Solubilization of insoluble inorganic zinc compounds by ericoid mycorrhizal fungi derived from heavy metal polluted sites. Soil Biol Biochem 35:133-141

Meharg AA, Cairney JWG (2000) Co-evolution of mycorrhizal symbionts and their hosts to metal-contaminated environments. Adv Ecol Res 30:69-112

Mergeay M, Monchy S, Vallaeys T, Auquier V, Benotmane A, Bertin P, Taghavi S, Dunn J, van der Lelie D, Wattiez R (2003) Ralstonia metallidurans, a bacterium specifically adapted to toxic metals: towards a catalogue of metal-responsive genes. FEMS Microbiol Rev 27:385-410

Moser AM, Frank JL, D'Allura JA, Southworth D (2009) Ectomycorrhizal communities of Quercus garryana are similar on serpentine and nonserpentine soils. Plant Soil 315:185-194

Nara K (2006a) Ectomycorrhizal networks and seedling establishment during early primary succession. New Phytol 169:169-178

Nara K (2006b) Pioneer dwarf willow may facilitate tree succession by providing late colonizers with compatible ectomycorrhizal fungi in a primary successional volcanic desert. New Phytol 171:187-198

Peiter E, Montanini B, Gobert A, Pedas P, Husted S, Maathuis FJM, Blaudez D, Chalot M, Sanders D (2007) A secretory pathwaylocalized cation diffusion facilitator confers plant manganese tolerance. PNAS-USA 104:8532-8537

Pilon M, Cohu CM, Ravet K, Abdel-Ghany SE, Gaymard F (2009) Essential transition metal homeostasis in plants. Curr Opin Plant Biol 12:347-357

Ruotsalainen AL, Markkola AM, Kozlov MV (2009) Mycorrhizal colonisation of mountain birch (Betula pubescens ssp czerepanovii) along three environmental gradients: does life in harsh environments alter plant-fungal relationships? Environ Monit Assess 148:215-232

Schat H, Llugany M, Bernhard R (2000) Metal-specific patterns of tolerance, uptake and transport of heavy metals in hyperaccumulating 
and nonhyperaccumulating metallophytes. In: Banuelos G, Terry N (eds) Phytoremediation of contaminated soil and water. Lewis, Boca Raton, pp 171-188

Sharples JM, Meharg AA, Chambers SM, Cairney JWG (2000) Mechanism of arsenate resistance in the ericoid mycorrhizal fungus Hymenoscyphus ericae. Plant Physiol 124:1327-1334

Simm C, Lahner B, Salt D, LeFurgey A, Ingram P, Yandell B, Eide DJ (2007) Saccharomyces cerevisiae vacuole in zinc storage and intracellular zinc distribution. Eukaryot Cell 6:1166-1177

Staudenrausch S, Kaldorf M, Renker C, Luis P, Buscot F (2005) Diversity of the ectomycorrhiza community at a uranium mining heap. Biol Fertil Soils 41:439-446

Turnau K, Gucwa E, Mleczko P, Godzik B (1988) Metal content in fruit-bodies and mycorrhizas of Pisolithus arrhizus from zinc wastes in Poland. Acta Mycol 33:59-67

Turnau K, Kottke I, Dexheimer J (1996) Toxic element filtering in Rhizopogon roseolus/Pinus sylvestris mycorrhizas collected from calamine dumps. Mycol Res 100:16-22

Turnau K, Przybyłowicz WJ, Mesjasz-Przybyłowicz J (2001) Heavy metal distribution in Suillus luteus mycorrhizas - as revealed by micro-PIXE analysis. Nucl Instrum Methods Phys Res Sect B Beam Interact Mater Atoms 181:649-658
Urban A, Puschenreiter M, Strauss J, Gorfer M (2008) Diversity and structure of ectomycorrhizal and co-associated fungal communities in a serpentine soil. Mycorrhiza 18:339-354

Utmazian MNDS, Schweiger P, Sommer P, Gorfer M, Strauss J, Wenzel WW (2007) Influence of Cadophora finlandica and other microbial treatments on cadmium and zinc uptake in willows grown on polluted soil. Plant Soil Environ 53:158-166

Verbruggen N, Hermans C, Schat H (2009) Molecular mechanisms of metal hyperaccumulation in plants. New Phytol 181:759-776

von Rozycki T, Nies DH (2009) Cupriavidus metallidurans: evolution of a metal-resistant bacterium. Antonie Leeuwenhoek 96:115-139

Vrålstad T, Myhre E, Schumacher T (2002) Molecular diversity and phylogenetic affinities of symbiotic root-associated ascomycetes of the Helotiales in burnt and metal polluted habitats. New Phytol 155:131-148

Wilkinson DM, Dickinson NM (1995) Metal resistance in trees-the role of mycorrhizae. Oikos 72:298-300

Willems G, Frérot H, Gennen J, Salis P, Saumitou-Laprade P, Verbruggen N (2010) Quantitative trait loci analysis of mineral element concentrations in an Arabidopsis halleri $\times$ Arabidopsis lyrata petraea $\mathrm{F} 2$ progeny grown on cadmium-contaminated soil. New Phytol 187:368-379 